\title{
ARTICLES
}

\section{SHARIAH-COMPLIANT SCREENING PRACTICES IN MALAYSIA}

\author{
Mohamed Azam Mohamed Adil, Catherine S.F. Ho, \\ Mansor Md. Isa, Ezani Yaakub, Mohammad Mahyuddin Khalid
}

\begin{abstract}
This study reviews twenty-eight users of Islamic equity screening in Malaysia based on the most recent information collected in 2012. Except for the Securities Commission and two index providers, the rest of the users are mutual fund companies. Our review indicates that, with few exceptions, the majority of the local screening users are following the benchmarks set by the Securities Commission of Malaysia, in which only industry screening is applied to separate Shariah compliant from non-compliant companies. A few users, however, employ a two-tier quantitative approach in addition to the qualitative screening. The qualitative screening removes companies whose main businesses are Shariah non-compliant. Companies with mixed activities are then subject to quantitative screenings in which non-compliant contributions are measured against applicable benchmarks. The Securities Commission is scheduled to have in place a two-tier quantitative screening method which is more in line with international practices by the end of 2013.
\end{abstract}

\section{Introduction}

Screening companies determine if certain investments are consistent with the Shariah principle requiring Muslim investors to invest only in Shariah-compliant firms and thereby confirm their permissibility for investors. However, given the modern day interdependence and linkages of business transactions, it is almost impossible to find a company that fully complies with the principles of the Shariah. A degree of tolerance therefore has to be exercised that allows Muslim investors to invest in companies with mixed activities, provided the Shariah noncompliant contribution to profit does not exceed a certain acceptable percentage. A team of international Shariah scholars has developed a screening methodology that paved the way for investors to own shares in public companies back in 1987 (Mian, 2008). These scholars presented a set of Shariah screening criteria and ruled that Muslim investors can purchase shares of companies that fulfil these criteria.

These screening criteria have been widely adopted, albeit with modifications, by Islamic financial markets around the globe. Basically the criteria consist of two levels, the business activity screen and financial ratio screen. For the business 
activity screen, a company must derive up to 95 percent of its revenue or profit from Shariah-compliant activities. This means that there is a 5 percent tolerance level in the total revenue or profit that may be derived from non-permissible sources, such as alcohol, tobacco, pork-related products, non-permissible entertainment, weapons and defence as well as conventional financial interestbearing services. For the financial ratio screen, a company would be accepted as Shariah-compliant if it meets the following criteria: total non-Shariah compliant debt should be less than 33 percent of equity; account receivables should not be more than 49 percent of total assets; and interest income should not be more than 5 percent of total income (Mian, 2008). However, the practice around the world seems to be inconsistent, as documented by Khatkatay and Nisar (2006), Derigs and Marzban (2008), Ho et al. (2011), and Ho et al. (2012).

The Bahrain-based Accounting and Auditing Organisation for Islamic Financial Institutions Sharia-compliant Standards (AAOIFI, 2010) aims to introduce a higher degree of harmonisation of Islamic finance practices across major Islamic finance markets in order to facilitate further expansion of the industry. The AAOIFI standards consist of a two-stage screening process of qualitative and quantitative screens. The qualitative screen is similar to that used by others: companies have to stay within what is lawful according to Shariah business activities. The quantitative screens used have total debt and interestbearing deposits being less than 30 percent of market capitalisation, and income generated from prohibited components less than 5 percent of total income. AAOIFI also excludes those involved in the issuance of conventional bonds, trading of futures, options and swaps contracts.

With different countries adopting their own standards, there is a lack of consistency for a universally acceptable compliance method and this may hamper growth in global Islamic investments. The different Shariah screening methodologies adopted by the Islamic financial industry also connote a lack of standardisation of the practices in the industry. There is therefore a need for Shariah scholars and industry players to consider greater standardisation of their screening methodologies to further the Islamic financial industry. Despite the controversies and uncertainties surrounding the issues of screening for Shariahcompliant companies, there is surprisingly very little analytical and empirical research in this area.

This paper aims to add to the much needed literature in this field. The aim of this paper is to review and analyse the Shariah-compliant screening methods currently practiced in Malaysia. Firstly, we discuss the current screening practices of the Malaysian Securities Commission. The Securities Commission is entrusted with the role of regulator of the local capital market. Since its establishment in 1993, it has been heavily involved in paving the way towards facilitating the development 
of Malaysia to be an international Islamic financial hub. Secondly, we present and analyse the qualitative and quantitative screening procedures as practiced by local financial institutions. This paper contributes to existing literature by documenting and analysing screening practices applied by Malaysian Islamic financial institutions. Since Malaysia is considered one of the major financial hubs for Islamic finance, it is important to share its practices with others, for greater understanding and harmonisation of practices at the international level.

Section two of the paper provides a review of existing literature on Shariah screening. The data collection and data profile are explained in Section three of the paper. Section four contains the presentation and discussion of the screening process used by local institutions and Section five summarises and concludes this paper.

\section{Review of Literature}

While there seems to be a reasonably strong consensus regarding what business activities are allowed in Shariah, controversy arises regarding companies with mixed activities. These include companies whose core activities are lawful but who out of necessity are also involved in unlawful transactions. As widely noted, it is extremely rare to find companies that are 100 percent Shariah-compliant in all their investing and financing activities. A more practical approach would be to develop filters that weed out companies whose Shariah non-compliant activities constitute a percentage beyond an acceptable benchmark.

It is common knowledge that certain business activities are prohibited in Islam. There is also consensus among all Islamic jurisdictions to prohibit business operations which involve giving and taking of interest; gambling; the production, distribution, promotion and sale of non-halal goods or services such as alcoholic beverages and pork; or immoral entertainment facilities such as prostitution, pubs, massage parlours and discos. Moreover, companies dealing with gharar that could lead to excessive speculation activities such as conventional insurance as explained by Derigs and Marzban (2008) are also considered as non-Shariah compliant. In addition, Naughton and Naughton (2000) and Iqbal and Mirakhor (2007) concluded that short selling, speculation and margin trading activities are not permissible in Islam, and this poses many challenges in structuring contemporary Islamic financial instruments and system. Khatkhatay and Nisar (2006) pointed out that Shariah-compatible investment is judged according to the investment structure and the nature of the contracting parties. Shariah prohibits interest-related investments, monetary obligation (debt, currency, liquid assets) and future rights (uncertainty).

Khatkhatay and Nisar (2006) compared and analysed screening criteria used by three organisations: Dow-Jones Islamic Index (US), Securities Commission (Malaysia) and Meezan Islamic Fund (Pakistan). The authors noted that among 
the three, Dow-Jones Islamic Index has the most comprehensive industry criteria in addition to a comprehensive set of financial criteria. Meezan also applied both industry and financial criteria while the Securities Commission of Malaysia, according to the authors, has the most liberal screening criteria. The Securities Commission does not apply any financial criteria but instead operates on a fourtier industry screening to exclude companies involved in various forms of nonShariah compliant activities. It seems that the Securities Commission is taking the approach of prioritising the Shariah prohibition of these activities; those that are strongly and clearly prohibited have the lowest tolerance level and those that are subject to much uncertainty have a more liberal benchmark. Khatkhatay and Nisar proposed that screen users not take into account percentages of nonpermissible income, but instead exclude all companies whose businesses are not 100 percent Shariah-compliant.

Derigs and Marzban (2008) provided a comparative study of screening practices on Shariah compliant stocks which have been adopted by nine groups of international users. The authors noted that all the users surveyed invariably use a two-tier screening process. First is an industry screen in which some users exclude companies with any level of involvement in non-Shariah compliant activities while others exclude only those whose primary activities are nonShariah compliant. Upon passing the industry screening, companies are subject to quantitative screenings that are divided into four categories: liquidity ratio, interest ratio, debt ratio and non-permissible ratio. Derigs and Marzban's (2008) main conclusion is that there are inconsistencies in the method of classification used by different groups, such that some stocks that are deemed permissible by one group may be non-permissible by other groups. The authors called for a more standardised screening framework across international users. Other studies, such as Shaikh (2010), Shariah Capital (2009) and Sengupta (2012), also found differences in Shariah compliant criteria acceptable to different Islamic investors.

In two recent studies, Ho et al. (2011) and Ho et al. (2012) reviewed the screening methods of equities among international Islamic finance uth objectives. Regulators such as the Securities Commission of Malaysia are more flexible; this approach is needed to rapidly develop the Islamic capital market in the country. Index providers, on the other hand, are concerned with the "purity" of the index in order to provide an accurate Islamic performance benchmark; hence they would apply a relatively strict screening method. Private asset managers catering to Middle Eastern investors would be more stringent in their interest screening as interest is a major concern for their clients. The authors also noted that, with only a few exceptions, most users employed quantitative screens for non-permissible income, followed by financial ratio screens. In general three financial ratios, 
namely debt ratio, liquidity ratio and interest to income ratio, are tested.

Although the above studies mention the use of financial ratios by various users, there is much uncertainty and inconsistency in the specification of the ratios as well as in the setting of the benchmarks. First, some of the users use percentages based on the market value of equities or total market capitalisation, which is market-based, while others were based on total assets, which is accountingbased. The use of both denominators has its merits and demerits, and it seems neither measure has a definite superiority over the other. Secondly, the setting of benchmarks is a matter of judgement by the Shariah jurists. There is no clear guidance on the cut-off points from the Shariah sources. Tolerance levels are set by Shariah advisors based on indirect inferences of the Quran and Hadith. It is therefore not surprising that there exists a great deal of variation in the benchmarks practiced by different users.

\section{Data Profile}

This study provides a fairly comprehensive compilation of Shariah screening methods of twenty-eight participants in the Islamic financial market in Malaysia, consisting of a market regulator, two Shariah index providers and twenty-five mutual fund management companies. The mutual fund companies are in turn affiliated with investment houses (13 companies), banks (nine companies) and insurance companies (three companies). Data used for this study consist of information on the screening methods applied by users that are collected from their respective websites. The information was collected during 2012. The list of users is presented in Table $1 .{ }^{1}$

Table 1 shows the compiled list that includes the Securities Commission and two Islamic index providers in addition to the twenty-five mutual fund companies. The index providers are FBM EMAS Shariah Index and FBM Hijrah Shariah Index. The mutual fund companies are affiliated with banks, insurance companies and investment houses. The banking institutions reviewed include Affin, Alliance, AmBank, Bank Islam, BSN, CIMB, Hong Leong, Public and RHB. These are the major banks in the country that provide not only banking services but also Islamic investment products. The insurance companies are ING, Prudential and MAA. They provide long term investment opportunities and manage them in accordance with Shariah principles. The thirteen investment houses are Amanah Raya, Apex, ECM Libra, Hwang DBS, Inter-Pacific, Kenanga, MIDF Amanah, OSK-UOB, Pacific, PMB, PNB, Pheim and TA. They provide an important function by pooling savings in long term investments which provide higher returns not only for investors within the country but for a large number of funds invested either regionally or globally. 


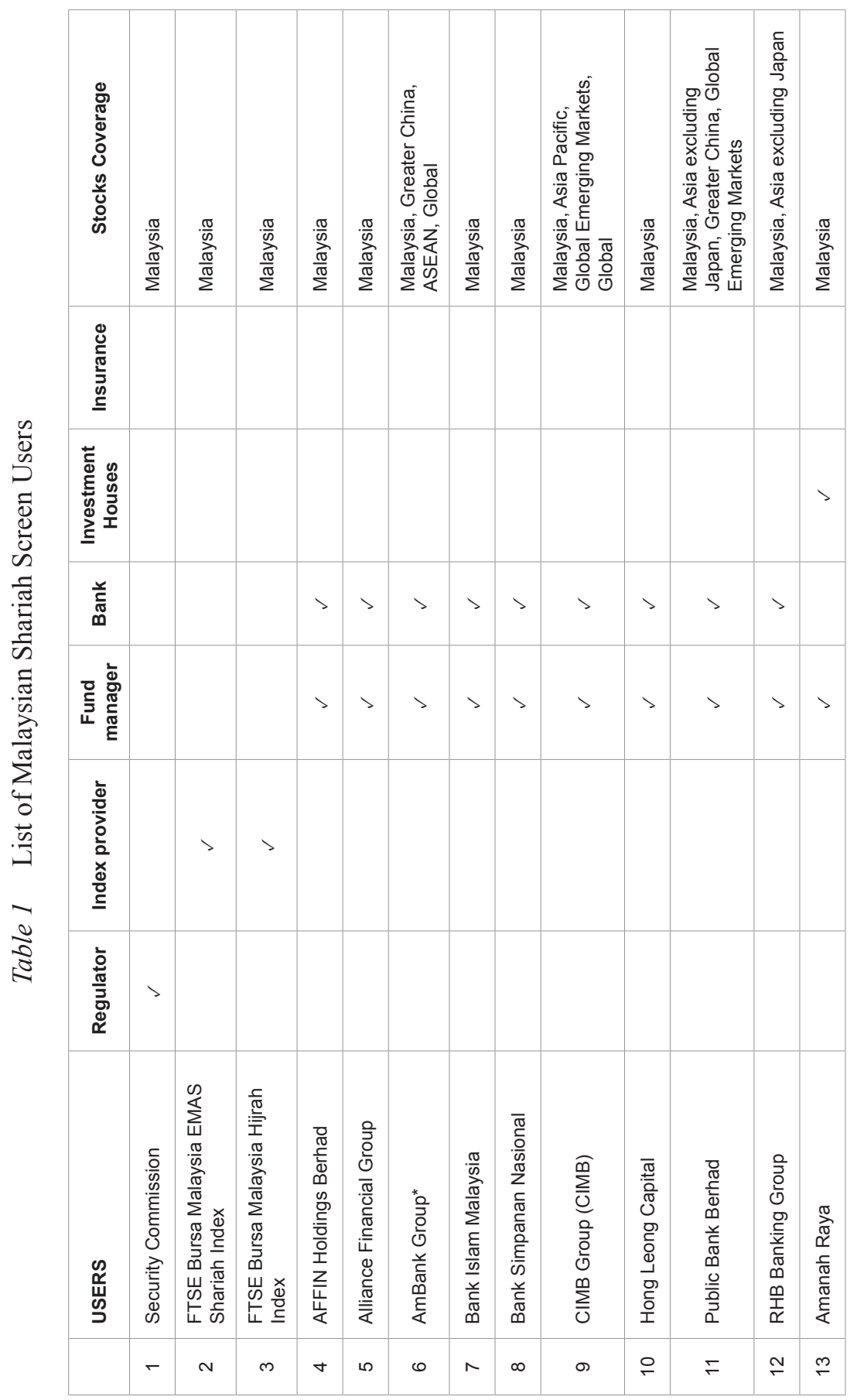




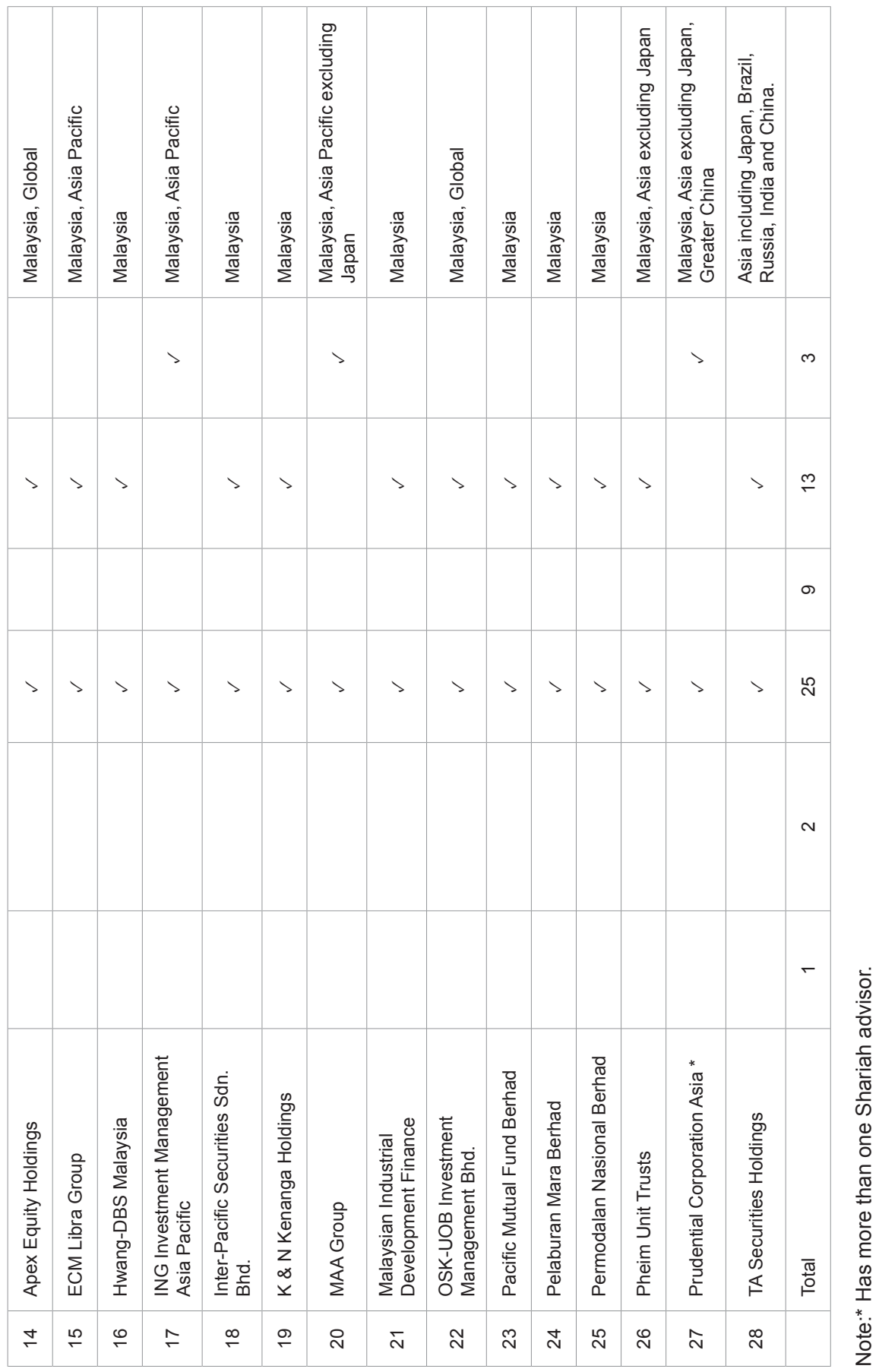


The Shariah screening process is generally carried out by in-house Shariah boards - international or local Shariah advisors which provide these institutions with Shariah related recommendations. These Shariah advisors may be profitoriented companies that provide Shariah compliant consulting and related services and therefore help to screen global assets based on demand. Similar to the other profit-oriented institutions, some institutions also possess their own Shariah boards and thereby apply their own screening methods. They also provide financial services by managing their own funds and those of their clients and screen selected global assets. Institutions with their own in-house Shariah boards include AmBank, Bank Islam, CIMB, RHB, Apex, MIDF Amanah and PNB. Those who do not have an in-house Shariah board have to consult independent Shariah advisors in order to comply with the regulatory requirements. Independent Shariah advisors include IBFIM, Amanie, Al-Rajhi, FTSE, Khalij, ZI Shariah Advisory or the Securities Commission of Malaysia. It should also be noted that some users, for example AmBank and Prudential, use more than one Shariah advisors.

\section{Findings and Discussions}

\section{The Securities Commission's Screen}

In 1995, with the establishment of its Shariah Advisory Council, the Securities Commission of Malaysia began to classify listed securities as Shariah-compliant or Shariah non-compliant. The screen used was basically the industry screen; that is, whether or not the business of the company is permissible by Shariah. If the main activity is not Shariah-compliant, the firm would be excluded. However, if the main activity is Shariah-compliant but there are elements of Shariah noncompliant activities, the company would be subjected to the filter tests, where the percentage contribution of non-permissible activities to total revenue or net profit would be measured against the appropriate benchmarks. The types of nonpermissible activities and their respective benchmarks are shown in Table 2.

With the rapid development in the Islamic financial market domestically as well as globally, the Securities Commission has decided to upgrade its screening procedure so that it is more in line with international practices and is also closer to the requirements of the Shariah. The new screening criteria, which are to be fully implemented by the end of 2013, will consist of a qualitative industry screen and two-tier quantitative screens (Securities Commission, 2013). The Securities Commission stated that "in view of the current development and sophistication of the Islamic finance industry, the screening methodology has now been revised by adopting a two-tier approach to the quantitative assessment which applies the business activity benchmarks and the newly introduced financial ratio 
benchmarks while at the same time maintaining the qualitative assessment" (Securities Commission, 2013). For ease of making comparisons, the old and new screening methods are summarised in Table 2.

Table 2 shows that the old screening method has four industry benchmarks. The contribution of Shariah non-compliant activities to the overall revenue or profits before taxes is measured against these benchmarks. There is no financial ratio screen used in the old method. As can be seen by the description of the categories, there exist considerable subjectivity and uncertainties in the classification of activities that is left to the discretion of the Shariah Advisory Council. In the new method, the number of industry benchmarks is reduced from four to only two, which are 5 percent and 20 percent. The 5 percent benchmark is for activities (a) and (b) in the old screen (see Table 2), while the 20 percent benchmark is for activities (c) and (d) in the old screen.

Table 2 Comparison of the Old and New Equity Screening Methods of the Malaysian Securities Commission

\begin{tabular}{|c|c|c|c|}
\hline & $\begin{array}{c}\text { Old } \\
\text { Benchmark }\end{array}$ & $\begin{array}{c}\text { New } \\
\text { Benchmark* }\end{array}$ & Activity \\
\hline \multirow{4}{*}{$\begin{array}{l}\text { Business } \\
\text { Activity } \\
\text { Benchmark }\end{array}$} & $5 \%$ & \multirow[t]{2}{*}{$5 \%$} & $\begin{array}{l}\text { a. Conventional banking; conventional } \\
\text { insurance; gambling; liquor and liquor- } \\
\text { related activities; pork and pork-related } \\
\text { activities; non-halal food and beverages; } \\
\text { Shariah non-compliant entertainment; } \\
\text { and other activities deemed non- } \\
\text { compliant according to Shariah. }\end{array}$ \\
\hline & $10 \%$ & & $\begin{array}{l}\text { b. Interest income from conventional } \\
\text { accounts and instruments; tobacco } \\
\text { and tobacco-related activities; and } \\
\text { other activities deemed non-compliant } \\
\text { according to Shariah. }\end{array}$ \\
\hline & $20 \%$ & \multirow{2}{*}{$20 \%$} & $\begin{array}{l}\text { c. Rental received from Shariah non- } \\
\text { compliant activities; and other activities } \\
\text { deemed non-compliant according to } \\
\text { Shariah. }\end{array}$ \\
\hline & $25 \%$ & & $\begin{array}{l}\text { d. Hotel and resort operations; share } \\
\text { trading; stock-broking business; and } \\
\text { other activities deemed non-compliant } \\
\text { according to Shariah. }\end{array}$ \\
\hline $\begin{array}{l}\text { Financial } \\
\text { ratio } \\
\text { Benchmark }\end{array}$ & None & $33 \%$ & $\begin{array}{l}\text { 1. Non-compliant cash deposit over total } \\
\text { assets } \\
\text { 2. Non-compliant debt over total assets }\end{array}$ \\
\hline
\end{tabular}

Note: *The new screen is applicable as of November 2013. 
In addition, the Securities Commission also proposes to screen financial ratios for the first time. Two ratios would be used: (1) cash over total assets and (2) debt over total assets. For the cash ratio, only cash placed in conventional accounts and instruments is included, whereas cash placed in Islamic accounts and instruments is excluded from the calculation. Likewise for the debt ratio, only interest-bearing debts are included in the calculation of the ratios, whereas Islamic debt and sukuk are excluded. Both ratios use balance sheet items and are measured against the same benchmark of 33 percent. It is obvious that these ratios are aimed at measuring the extent of non-compliance in the non-Islamic financial transactions of the company. The benchmark of 33 percent probably has its root in the well-known Hadith of the Prophet that limits donation to onethird of one's wealth (Obaidullah, 2005). This benchmark is also used in the screening standards of developed markets such as the DJ, FTSE, S\&P and MSCI (Derigs and Marzban, 2008). However, the Securities Commission's definition of cash and total debt includes only the non-compliant component and is considered more appropriate than others that use total debt and total cash whether they are Islamic or not.

There are two positive observations in the new method. First, it is simpler than the old method because a lesser number of benchmarks is used in the industry screen. This should pave the way for a quicker and more economical calculation process. It would also expedite the extraction of relevant information from the companies. Secondly, the idea of using a financial ratio has gained momentum in the international market, and this is included in the new screening method. The financial ratios are aimed at measuring the extent to which the financial management of companies complies with the Shariah principles. Again, with only two ratios to calculate, this would expedite the calculation and classification of companies.

On the negative side, the new screening method is somewhat more restrictive, and this may result in the exclusion of companies that were previously classified as Shariah-compliant by the old standards. This possibility has been alluded to by Abdul-Rahman et al. (2010), who found a drastic reduction in the Shariahcompliant universe when the DJIS screens were applied to the local listed stocks. The upshot of this is that, in the short run, local investors may have fewer companies listed in their Shariah-compliant universe. In the long run, however, it is expected that companies will respond positively to these benchmarks and adjust their operations accordingly in order to qualify for the coveted Shariahcompliant status. One implication of this limitation in the local Shariah-compliant investment field is that local investors may have to look for international diversification of their portfolios. 


\section{Qualitative Screen}

All twenty-eight institutions included in this review employ a two-stage screening process. The first process is the industry screen. This is a qualitative screening based on whether the main business activity of the company is Shariah-compliant or non-compliant. Companies that pass the industry screen are then subject to quantitative screening. Shariah non-compliant businesses may be classified into five categories based on the nature of the business: riba and gharar; non-halal products; gambling and gaming; immoral activities; and other impermissible activities. This study compiled all prohibited activities as stated by each institution and their respective Shariah advisor or board. In general we find that there is a high degree of agreement among all institutions regarding non-permissible business activities. This is hardly surprising because these prohibitions have clear Shariah rulings on them. The only difference among the users is in the detailed specification of these activities.

We analyse the qualitative information provided by the users in Table 3. For users with multiple Shariah advisors, there are variations among the advisors in the specification of non-compliant activities. Table 3 tabulates the frequency each item is mentioned by the advisors. The information may be summarised as follows:

In terms of riba and gharar activities, the main activities mentioned are conventional financial services, which are riba-based banking and insurance. Many users also include stock-broking or share trading in non-Shariah stocks in this category.

Because non-halal products are very clearly defined, there is no variation in the screening by the users. Basically any form of business activity associated with liquor or pork is included.

Gambling and gaming businesses in their various forms are clearly prohibited in Islam and therefore there is no variation in the screen used.

Regarding immoral activities, the most frequently mentioned is "nonpermissible entertainment" and pornography. A few users specifically mentioned music, hospitality services, movies and recreations as not permissible in Shariah.

Other impermissible businesses include tobacco products, weapons and defence product manufacturing.

In summary, there is definitely a clear list of activities that are Shariah noncompliant and the majority of institutions have a comprehensive list of them. Companies whose main activities are prohibited by Shariah are deemed Shariah non-compliant and would be rejected, while those that are not involved in any of the prohibited activities are deemed to be Shariah-compliant. This leaves companies with mixed activities that would be subjected to further tests. 
Table 3 Shariah Non-Compliant Business Activities: Frequency Distribution

\begin{tabular}{|c|c|c|}
\hline Business Activity & Frequency & Percentage $(\%)^{*}$ \\
\hline \multicolumn{3}{|l|}{ Riba and Gharar } \\
\hline Conventional financial services & 25 & 75.53 \\
\hline Conventional banking & 7 & 20.59 \\
\hline Conventional insurance & 16 & 47.06 \\
\hline Stock broking in non-compliant stocks & 12 & 35.29 \\
\hline Riba-based financial activities & 8 & 23.53 \\
\hline Others & 2 & 5.88 \\
\hline \multicolumn{3}{|l|}{ Non-halal products } \\
\hline Non-halal products & 29 & 70.59 \\
\hline Liquor and related products & 24 & 64.71 \\
\hline Pork and related products & 22 & 41.18 \\
\hline Others & 0 & 0 \\
\hline \multicolumn{3}{|l|}{ Gambling and gaming } \\
\hline Gambling, casinos, lottery & 34 & 100.00 \\
\hline Gaming & 20 & 58.82 \\
\hline Others & 0 & 0 \\
\hline \multicolumn{3}{|l|}{ Immoral activities } \\
\hline Non-permissible entertainment & 30 & 88.24 \\
\hline Pornography & 24 & 70.59 \\
\hline Music & 6 & 17.65 \\
\hline Hospitality, hotels, resorts & 5 & 14.71 \\
\hline Cinemas, movies & 5 & 14.71 \\
\hline Recreation & 4 & 11.76 \\
\hline Others & 3 & 8.82 \\
\hline \multicolumn{3}{|l|}{ Other Impermissible } \\
\hline Tobacco and related activities and & & \\
\hline products & 32 & 94.12 \\
\hline Weaponry and defense & 21 & 61.76 \\
\hline Other non-permissible activities & 32 & 94.12 \\
\hline
\end{tabular}

*The percentages are based on 34 Shariah Advisors of the 25 users. 


\section{Quantitative Screening}

Companies with a mixture of Shariah and non- Shariah compliant activities are subject to quantitative screening to test the extent of non-Shariah contribution to the business. Quantitative screening may be subdivided into two categories: nonpermissible business percentage and financial ratios.

\section{Non-Permissible Income Screening}

At this stage, non-permissible activities identified from the initial business screening are further quantified to check if their level is acceptable by the respective institutions. Table 4 shows the benchmark used by the institutions to test for the contribution of the non-Shariah activities. It can be seen from the table that the Securities Commission operates a four-tier benchmark of non-permissible income: the clearly prohibited activities have a very restrictive benchmark of 5 percent, followed by umum balwa (commonly practiced forms of business) activities with a 10 percent benchmark, mixed rental payment, 20 percent and maslahah (public interest) activities, 25 percent. Recall that these are exactly the same classifications as presented in Table 2 earlier. It is also clear from the table that, with few exceptions, every institution applies the classification of the Securities Commission. This is to be expected as it is a regulatory requirement that all Islamic mutual fund companies comply with the Securities Commission's classification.

It is interesting to note that twelve of the twenty-five mutual funds have overseas investments (see Table 1) and the screening of these overseas investments is beyond the Securities Commission regulation. Table 4 shows that even those investing overseas do not apply their own screening, except for one user, AmBank, which may be considered a special case in that it has five different Shariah advisors with differences in their screening methods: one advisor follows the Securities Commission's classification; two advisors have a flat 5 percent screen for all types of non-compliant contributions; and two advisors do not have any quantitative screening at all, which means that a company involved in any form of non-compliant activities, regardless of the amount, would be excluded.

It is further noted that the benchmarks operate on two denominators: total revenue and profit before tax. There are two tests for each benchmark: the first is the gross contribution from the non-compliant sector divided by the gross revenue of the firm. The second is net contribution before tax of the sector, divided by total profit before tax of the firm. Violation of either of these tests would result in the company being dropped from further consideration. Companies that fail the non-permissible income screening are deemed to be Shariah non-compliant, while those that pass the test are further subjected to financial ratio-tests. 
Table 4 Benchmark for Non-permissible Income

\begin{tabular}{|c|c|c|c|c|c|}
\hline & USERS & $\begin{array}{c}\begin{array}{c}\text { Clearly } \\
\text { prohibited }\end{array} \\
\frac{x \%}{T R \text { and } P B T}\end{array}$ & $\begin{array}{c}\begin{array}{c}\text { Umum } \\
\text { balwa }\end{array} \\
x \% \\
T R \text { and } P B T\end{array}$ & $\begin{array}{c}\begin{array}{c}\text { Mixed } \\
\text { rental } \\
\text { payment }\end{array} \\
\frac{x \%}{T R \text { and } P B T}\end{array}$ & $\begin{array}{c}\text { Maslahah } \\
\frac{x \%}{T R \text { and } P B T}\end{array}$ \\
\hline 1 & Securities Commission (SC) & $5 \%$ & $10 \%$ & $20 \%$ & $25 \%$ \\
\hline 2 & FBM EMAS Shariah Index & \multicolumn{4}{|c|}{ SC } \\
\hline 3 & FBM Hijrah Shariah Index & \multicolumn{4}{|c|}{ SC } \\
\hline 4 & Affin & \multicolumn{4}{|c|}{ SC } \\
\hline 5 & Alliance & \multicolumn{4}{|c|}{ SC } \\
\hline & & \multicolumn{4}{|c|}{ SC } \\
\hline & & \multicolumn{4}{|c|}{$<\frac{5 \%}{T Y}$} \\
\hline & AmBank & \multicolumn{4}{|c|}{ None } \\
\hline 6 & & \multicolumn{4}{|c|}{ None } \\
\hline & & \multicolumn{4}{|c|}{$<\frac{5 \%}{T Y}$} \\
\hline 7 & Bank Islam & \multicolumn{4}{|c|}{ SC } \\
\hline 8 & BSN & \multicolumn{4}{|c|}{ SC } \\
\hline 9 & CIMB & \multicolumn{4}{|c|}{ SC } \\
\hline 10 & Hong Leong & \multicolumn{4}{|c|}{ SC } \\
\hline 11 & Public & \multicolumn{4}{|c|}{ SC } \\
\hline 12 & RHB & \multicolumn{4}{|c|}{ SC } \\
\hline 13 & Amanah Raya & \multicolumn{4}{|c|}{ SC } \\
\hline 14 & Apex & \multicolumn{4}{|c|}{ SC } \\
\hline 15 & ECM Libra & \multicolumn{4}{|c|}{ SC } \\
\hline 16 & HwangDBS & \multicolumn{4}{|c|}{ SC } \\
\hline 17 & ING & \multicolumn{4}{|c|}{ SC } \\
\hline 18 & Inter-Pacific & \multicolumn{4}{|c|}{ SC } \\
\hline 19 & Kenanga & \multicolumn{4}{|c|}{ SC } \\
\hline 20 & MAA & \multicolumn{4}{|c|}{ SC } \\
\hline 21 & MIDF Amanah & \multicolumn{4}{|c|}{ SC } \\
\hline 22 & OSK-UOB & \multicolumn{4}{|c|}{$\mathrm{SC}$} \\
\hline 23 & Pacific & \multicolumn{4}{|c|}{ SC } \\
\hline 24 & PMB & \multicolumn{4}{|c|}{ SC } \\
\hline 25 & PNB & \multicolumn{4}{|c|}{ SC } \\
\hline 26 & Phoim & \multicolumn{4}{|c|}{ SC } \\
\hline 26 & Pheim & & & & \\
\hline 27 & Prudential & & & & \\
\hline 27 & Prudential & & & & \\
\hline 28 & TA & & & & \\
\hline
\end{tabular}

Note: SC indicates that the institution simply follows the classification of the Security Commission. 


\section{Financial Ratio Screen}

Use of financial ratios is basically confined to screening of companies' nonShariah operations. It is vital to understand that Shariah strongly prohibits riba or interest in any form of business or financial transaction. Conventional borrowing and lending, which is interest-based, is therefore not Shariah-compliant. Many scholars are of the view that it is necessary to screen non-compliant financial operations of the companies by looking at selected financial ratios. Previous studies classified financial ratios screening into three types: debt, liquidity and interest. Debt screening is to weed out companies involved in excessive borrowing, while liquidity screening is aimed at assessing the amount of cash and liquid assets. Interest screening is of course to filter the amount of interest income to total income. The interest screen is not included here because interest income will have already been screened either in the qualitative stage or in the non-permissible income stage. Table 5 reports the results of the twenty-eight screen users.

Our compilation of results of the screen users reveals only four users of debt ratio screening - FBM Hijrah Shariah Index, AmBank, CIMB and Prudential. All other users seem to follow the Securities Commission in not having any financial ratio screening. AmBank alone employs five different Shariah advisors with each specifying its own debt ratio screen. The debt ratio benchmark is either 30 or 33 percent, while the denominator used is either total assets or market capitalisation value of equity. Readers interested in exploring the justification for the benchmarks as well as the denominators should refer to previous studies such as Khatkatay and Nisar (2006) and Derigs and Marzban (2008).

Liquidity measures applied by the users and their Shariah advisors consist of three types: accounts receivables, receivables plus cash and cash plus conventional deposits. Similar to debt screening, only four users (eight advisors) apply liquidity screening. Since the Securities Commission of Malaysia has not imposed any official restrictions on liquidity, those institutions that follow the Securities Commission regulation have not set any limit on liquidity. Shariah boards of Amanie, AmBank, Al-Rajhi and CIMB apply a 33 to 49 percent benchmark to total receivables over total assets or market value of equity. FTSE as the Shariah advisor for the FBM Hijrah Shariah Index is the only board that applies receivables plus cash of 50 percent limit over total assets. For cash plus conventional deposits, the limit varies between 30 percent and 33 percent of total assets or market value of equity. 
Table 5 Financial Ratio Screen

\begin{tabular}{|c|c|c|c|c|c|}
\hline \multirow[t]{2}{*}{ User } & \multirow[t]{2}{*}{ Shariah Advisor } & \multirow{2}{*}{$\begin{array}{c}\begin{array}{c}\text { Debt } \\
\text { Screen }\end{array} \\
\text { Total } \\
\text { Debt }\end{array}$} & \multicolumn{3}{|c|}{ Liquidity Screen } \\
\hline & & & Receivables & $\begin{array}{c}\text { Receivables } \\
+ \text { Cash }\end{array}$ & $\begin{array}{l}\text { Cash } \\
+ \text { IBS }^{*}\end{array}$ \\
\hline $\begin{array}{l}\text { Securities } \\
\text { Commission }\end{array}$ & SAC & & & & \\
\hline $\begin{array}{l}\text { FBM EMAS } \\
\text { Shariah Index }\end{array}$ & Securities Commission & & & & \\
\hline $\begin{array}{l}\text { FBM Hijrah } \\
\text { Shariah Index }\end{array}$ & FTSE, SC & $\frac{33 \%}{T A}$ & & $\frac{50 \%}{T A}$ & $\frac{33 \%}{T A}$ \\
\hline Affin & IBFIM & & & & \\
\hline Alliance & IBFIM & & & & \\
\hline \multirow{5}{*}{ AmBank } & Amanie Advisors Sdn. Bhd. & $\frac{33 \%}{M V E q}$ & $\frac{49 \%}{M V E q}$ & & $\frac{33 \%}{M V E q}$ \\
\hline & Khalij Islamic (BVI) Limited & $\frac{30 \%}{\text { MCap }}$ & & & $\frac{30 \%}{\text { MCap }}$ \\
\hline & Shariah Advisory Board & $\frac{33 \%}{\text { AvMCap }}$ & $\frac{45 \%}{\text { AvMCap }}$ & & $\frac{33 \%}{\text { AvMCap }}$ \\
\hline & Shariah Supervisory Board & $\frac{33 \%}{\text { AvMCap }}$ & $\frac{33 \%}{\text { AvMCap }}$ & & $\frac{33 \%}{\text { AvMCap }}$ \\
\hline & $\begin{array}{l}\text { Al Rajhi Banking \& } \\
\text { Investment Corp (M) Bhd }\end{array}$ & $\frac{30 \%}{\text { MCap }}$ & $\frac{45 \%}{\text { AvMCap }}$ & & $\frac{30 \%}{\text { MCap }}$ \\
\hline Bank Islam & Shariah Panel, SC & & & & \\
\hline $\mathrm{BSN}$ & IBFIM & & & & \\
\hline CIMB & CIMB Islamic Bank Berhad & $\frac{30 \%}{\text { AvMCap }}$ & $\frac{45 \%}{T A}$ & & $\frac{30 \%}{\text { AvMCap }}$ \\
\hline Hong Leong & Amanie Advisors, SC & & & & \\
\hline Public & ZI Shariah Advisory Services & & & & \\
\hline RHB & RHB Islamic Bank Berhad & & & & \\
\hline Amanah Raya & IBFIM & & & & \\
\hline Apex & Shariah Committee, SC & & & & \\
\hline ECM Libra & IBFIM & & & & \\
\hline HwangDBS & IBFIM & & & & \\
\hline ING & IBFIM & & & & \\
\hline Inter-Pacific & Amanie Advisors & & & & \\
\hline Kenanga & IBFIM & & & & \\
\hline MAA & IBFIM & & & & \\
\hline MIDF Amanah & MIDF Shariah Committee & & & & \\
\hline OSK-UOB & IBFIM & & & & \\
\hline Pacific & BIMB Securities & & & & \\
\hline PMB & BIMB Securities & & & & \\
\hline PNB & Shariah Committee & & & & \\
\hline \multirow{2}{*}{ Pheim } & Amanie Advisors & & & & \\
\hline & IBFIM & & & & \\
\hline \multirow{2}{*}{ Prudential } & Amanie Advisors & $\frac{33 \%}{A v M C a p}$ & $\frac{45 \%}{M C a p}$ & & \\
\hline & IBFIM & & & & \\
\hline TA & IBFIM & & & & \\
\hline
\end{tabular}

Note: ${ }^{*}$ BSS $=$ Interest bearing securities. 
It should be mentioned that the use of a financial ratio is still subject to much debate, both in the ratio specification as well as in the critical cut-off point. For example, should we include all debts or just conventional debts in calculating the debt ratio? Filtering the involvement of companies in interest-based financing has merit in the sense that this is a clearly prohibited transaction, but there is no clear Shariah ruling on companies operating on high leverage if the debts are Shariah-compliant. Secondly, it may be understandable to screen for cash placed in conventional money-market instruments and other short-term deposits, not as a measure of liquidity per se, but rather as an additional measure of Shariah noncompliance in financial management. This is indeed the position taken by the Securities Commission in its new screening methodology. However, there is an alternative view as explained by Khatkatay and Nisar (2006) and Shaikh (2010), that Islam does not allow income to be derived from liquid assets. According to this view the market value of liquid assets is equal to the residual of the market value of equity after netting out fixed assets and external financing. Some Islamic scholars have stated that there should be a limit to this market value of liquid assets. Flaws to this approach have been pointed out by Khatkatay and Nisar (2006).

\section{Summary and Conclusion}

This study reviews twenty-eight equity screen users in the Malaysian Islamic capital market. The objective of this review is to document the various screening processes and to draw out common rules and practices. The users are mainly mutual fund managers affiliated with various financial institutions such as investment houses, banks and insurance companies. The comprehensive data also include the Securities Commission and two major Shariah index providers. Information on the screening practices is obtained from the official sites of the respective users and their financial advisors during 2012.

The foremost screen provider in the Malaysian Islamic capital market is the Securities Commission, the capital market regulator, which began to screen for Shariah-compliant securities in 1995. The Securities Commission, with the overriding objective to develop the Islamic capital market, employs a more liberal screening process that allows more securities to be classified as Shariahcompliant. The screen applied is the industry screen that filters companies based on the percentage of the Shariah non-compliant component in the companies' income. Nevertheless, the Securities Commission has announced that it would begin to apply the industry as well as financial ratio screens beginning in November 2013, a move that is seen as more in line with international practices. 
Reviewing the practices of the rest of local screen users, it is found that the majority of these users follow the practice of the Securities Commission. We also found that all users apply both qualitative and some form of quantitative screening processes. The qualitative screen filters companies that are clearly Shariah non-compliant based on their main business activities. Those passing the qualitative screen are then subjected to non-permissible income screening, which is the first part of the quantitative screening. In this stage the percentage contribution of various non-permissible incomes is measured against their respective benchmarks. Those passing this stage are further tested by financial ratio screening. Two ratios are basically applied in the financial ratio screening - debt ratio and cash ratio - and these are measured against pre-determined benchmarks. Most users apply either a 30 percent or 33 percent benchmark based on either total assets or equity market values.

\section{Policy Recommendations}

- From a policy standpoint, the Securities Commission needs to strike a balance in its role between regulating and developing the Islamic capital market. A strict screening standard would have the effect of reducing the universe of Islamic securities and thus curtail the development and growth of the Islamic capital market. On the other hand, too liberal screening processes may jeopardise the local market in the eyes of international Islamic investors.

- The move to use financial ratios in addition to the simplification of the current non-permissible income screening may be considered as the right combination to move forward.

- Shariah screening would result in only a subset of the entire market being available to Islamic investors, putting them at a disadvantage from the perspective of an efficient portfolio.

- It is hoped that more securities would be encouraged to be Shariah-compliant in the future and in the meantime investors should aggressively screen international securities to expand their investment universe in order to achieve equitable returns.

- Debt is a worrying problem and a major driver of financial crises. Hence the limits on debt-based trade and finance should be carefully observed. This recommendation stands for both Islamic and conventional finance.

- Furthermore, regulatory authorities and government should reconsider the tax incentives given to debt-based financing. At present debt- and credit-based financing is preferred to asset-backed transactions simply because of the tax advantages for debt, which make it more appealing. These incentives should be reconsidered. 


\section{References}

AAOIFI (2010). AAOIFI Accounting, Auditing and Governance Standards 2010, www.aaoifi.com

Abdul-Rahman, A., Yahya, M.A. and Mohd-Nasir, M.H. (2010). Islamic Norms for Stock Screening: A comparison between the Kuala Lumpur Stock Exchange Islamic Index and the Dow Jones Islamic Market Index, International Journal of Islamic and Middle Eastern Finance and Management, 3(3), 228-240.

Derigs, U. and Marzban S. (2008). Review and Analysis of Current Shariah-compliant Equity Screening Practices, International Journal of Islamic and Middle Eastern Finance and Management, 1(4), 285-30.

Ho, C.S.F., Abd-Rahman, N.A., Yusuf, N.H.M. and Zamzamin, Z. (2011). Comparison of Quantitative Shariah-Compliant Screening Methods, International Journal of Islamic Finance, 3(2), 91-109.

Ho, C.S.F., Masood, O., Abdul-Rehman, A. and Bellalah, M. (2012). Syariah Accounting and Compliant Practices, Qualitative Research in Financial Markets, 4(2), 24-254.

Iqbal, Z. and Mirakhor, A. (2007). An Introduction to Islamic Finance: Theory and Practice, Singapore: John Wiley \& Sons (Asia).

Khatkhatay, M.H. and Nisar, S. (2006). Shariah-Compliant Equity Investments: An Assessment of Current Screening Norms, Proceedings of the Seventh Harvard University Forum on Islamic Finance, Harvard University.

Mian, K.M. (2008). Shariah Screening and Islamic Equity Indices, Hedge Fund Monthly, viewed 15 February, 2013. http://www.eurekahedge.com

Naughton, S. and Naughton, T. (2000). Religion, Ethics and Stock Trading: The Case of an Islamic Equities Market, Journal of Business Ethics, 23, 145-159.

Obaidullah, M (2005). Islamic Financial Services, Scientific Publishing Center, King Abdul Aziz University, Jeddah.

Securities Commission (2009). Approved Syariah Principles and Concepts for the Purpose of Structuring, Documenting and Trading of Islamic Securities, viewed March 2009. http://www.sc.com.my

Securities Commission (2013). Frequently asked questions on the revised Shariah screening methodology, Accessed in February 2013. http://www.sc.com.my

Sengupta, B. (2012). Sharia Stock Screening: A Fund Manager's Conundrum, Cognizant, viewed 28 February 2013. http://www.cognizant.com/InsightsWhitepapers/Sharia-Stock-Screening-A-FundManagers-Conundrum.pdf

Shaikh, S. (2010). Analysis of Stock Screening Principles in Islamic Mutual Funds Industry, viewed 31 March 2011. http://mpra.ub.uni-muenchen.de/19755/

Shariah Capital (2009). Shariah Capital: Expanding the Universe of Shariah Compliant Stocks, viewed 9 March, 2009. http://www.shariahcap.com/pubs/Shariah/Shariah_screening.pdf

\section{Notes}

* Mohamed Azam Mohamed Adil is Deputy CEO cum Principal Fellow at IAIS Malaysia, and Associate Professor at Universiti Teknologi MARA (UiTM), Shah Alam, Malaysia.

Catherine S. F. Ho is the Head of the Centre for Finance, Insurance, Economics and Islamic Banking Studies at the Faculty of Business Management, Universiti Teknologi MARA (UiTM), Shah Alam.

Mansor Md. Isa is Professor of Finance at the Faculty of Business and Accountancy, University of Malaya. He is now attached with Capital Market Authority, Saudi Arabia.

Ezani Yaakub is Deputy Dean, Research and Industrial Linkages, Academy of Contemporary Islamic Studies (ACIS), Universiti Teknologi MARA (UiTM) Shah Alam, specialised in Islamic Economics.

Mohammad Mahyuddin Khalid is a lecturer at Academy of Contemporary Islamic Studies (ACIS), Universiti Teknologi MARA (UiTM) Shah Alam, specialised in Islamic Economics.

1. Our attempts to obtain information from other investment institutions such as EPF, KWAP, LTAT, Takaful and Tabung Haji have not been successful. Therefore we are unable to include them in our analysis. 